\title{
INFLUENCE OF DIFFERENT TREATMENTS OF GUAR KORMA MEAL ON SHEEP PERFORMANCE
}

\author{
A.M. Shwerab; M.S. Khalel; Amany A. Khayyal; A.A. Hassan and M.H. Yacout \\ Department of By-Products Utilization, Animal Production Research Institute, Agriculture Research \\ Center, Dokki, Giza, Egypt.
}

(Received 15/1/2015, accepted 3/3/2015)

\section{SUMMARY}

$\mathrm{T}$ he present study was conducted to study the effect of heat, soaking, chemical (ethanol) or biological (bacteria) treatments of Guar korma meal (GKM) on concentration of anti-nutritive compounds, rumen fermentation characteristics, microbial counts, degradability of tested TMR's, the blood picture and the consequently sheep performance was also studied. The total mixed rations (TMR's) were: 1- TMR without GKM (control); 2- TMR with 10\% untreated GKM (TMRU), 3- TMR with 10\% heated GKM (TMRH), 4- TMR with 10\% soaking GKM (TMRS), 5- TMR with 10\% GKM treated with ethanol (TMRE) and 6- TMR with 10\% GKM treated with lactic acid bacteria (TMRB). Digestibility trials were conducted with Barki rams, while rumen fermentation trials were conducted with fistulated Barki ewes. Feeding trials were applied with thirty male growing lambs, whereas they were randomly divided into six similar groups according to their body weights for a feeding period of 120 days, where weight was recorded and blood samples were collected. All treatments, showed a positive effect in decreasing concentration of anti-nutritive compounds. TMRB had highest feeding values, nitrogen utilization, higher VFA's concentration and higher rates of ammonia-N and VFA's productions, while, lowest ammonia-N concentration was recorded with TMRH. Total bacteria count was increased with all treatments comparing with TMRU, while protozoa counts were decreased with incorporating untreated or treated GKM in TMR's comparing with control. Microbial protein was ranged between 54.16 and 100.62 (gm/day) for untreated GKM and LAB treated GKM containing TMR's with significant differences. Effective degradability "ED" $(\%)$ of DM were higher $(\mathrm{P}<$ 0.05 ) for TMR's containing biologically and chemically treated GKM. Highest effective degradability of CP was recorded with TMRB with significant differences with other TMR's. However, lower effective degradability of CP was recorded with TMR's containing GKMH and GKMU. Highest daily gain was recorded with LAB treated GKM containing TMR. The lowest daily gain was recorded by sheep fed ration contained untreated GKM. The economic cash return (L.E/head/d) was more profit for ration contained GKMB and GKME than other total mixed rations. Except for cholesterol, total protein, albumin, globulin and their ratio the other serum metabolites of the experimental lambs were not significantly influenced by the dietary treatments. It could be concluded that the lactic acid bacteria treated GKM could be used at $10 \%$ in TMR for sheep. Chemically treated GKM by ethanol could be also used at $10 \%$ without any adverse effects on sheep performance. However, it is important to carry out further research on long term feeding of sheep to follow metabolites compounds consequential in blood, milk and meat.

Keywords: guar korma meal, detoxification, sheep, digestibility, rumen fermentation, microbial count, degradability, blood analyses, growth performance.

\section{INTRODUCTION}

In Egypt there is a serious problem resulting from a shortage of protein sources gives every scope to search for alternate protein sources for sustaining production and reducing the cost of animal feed. Therefore, there is a need to evaluate alternative protein sources. Guar (Cyamopsis tetragonoloba L.), which is a drought resistant annual legume predominantly grown in semi-arid and sub-tropical areas in India and Pakistan (APEDA, 2011). Khalil (2001) cited that in Egypt nowadays several attempts for planting guar were successfully carried out and the yield amounted to about 1.2 tones per acre. Such production is similar to faba bean (Nassib et al., 1991). The plant is primarily grown for its galactomannan polysaccharide gum, which has numerous industrial and food processing applications (Mishra et al., 2013). Guar meal (GM), a by-product of guar gum isolation, contains 33 to $45 \%$ protein, which is valued by livestock producers (Salehpour and Qazvinian, 2011). It is a mixture of germs and hulls at an approximate ratio of $25 \%$ germ to $75 \%$ hull (Turki et al., 2011). Kamran et al. (2002) 


\section{Shwerab et al.}

reported that the high amino acid content of the GM protein makes it a useful protein supplement. This is mostly used as a source of protein in ruminant and monogastric animals (Jahani-Azizabadi et al., 2010). Since the germ fraction of GM contains energy, protein, methionine and phosphorus in higher levels than that in soybean meal (Kamran et al., 2002). Nutritive values have been determined: $\mathrm{N}$ degradability for expanded GM is in the $65-75 \%$ range and is influenced by the amount of heat treatment. N degradability for unprocessed meal was $85 \%$ (Lund et al., 2008). Approximately $88 \%$ of the nitrogen content in GM was true protein with arginine content approximately twice that of soybean meal. Currently, GM is sold at about half the price of soybean meal, making it an appealing potential source of protein in animal feeds (Shahbazi, 2012). It is used as a feed ingredient but may require processing to improve palatability and remove anti nutritional factors (Turki et al., 2011). Although this by-product meal contains protein concentrations that range from 36 to $45 \%$ protein, early research with guar meal revealed deleterious effects on feed consumption; feed conversion and body weight gain of animal fed rations (Huston and Shelton, 1971 and Rajput et al., 1987). These effects were attributed to the high level of anti-nutritive compounds such as saponins; trypsin inhibitor; poly phenolics, phytic acid; tannins and residual gum (Lee et al., 2004; Ahmed et al., 2006; Tran, 2013 and Nidhina and Muthukumar, 2015). Hussain et al. (2012) reported that inclusion of GM in rations can be maximized by adopting proper processing techniques and by the use of certain additives. Anti-nutritive compounds can be mitigated by various treatments. Tasneem and Subramanian (1990) cited that elimination of GM could be occurred by different methods, it includes solvent extraction, heat, soaking and microbial fermentation. The aim of this study was to investigate the effect of heat, soaking, chemical (ethanol) and biological (bacteria) treatments on degrading toxin compounds in guar korma meal, on rumen fermentation characteristics and their effect on lambs performance.

\section{MATERIALS AND METHODS}

This experiment was conducted at Noubaria Experimental Station, Animal Production Research Institute, Agriculture Research Center. Regular non roasted guar korma meal (GKM) obtained from the commercial Egyptian company.

\section{Detoxification methods:}

\section{Heat treatment:}

Guar korma meal was heated in boiling water for $15 \mathrm{~min}$ to inactivate the anti-nutritional compounds, after boiling the excess water was drained off and treated sample was air dried at room temperature (Gorrill et al., 1974) then they stored in plastic containers until used.

\section{Soaking treatment:}

Guar korma meal was soaked in distilled water $(1: 3 \mathrm{w} / \mathrm{v})$ for $12 \mathrm{~h}$ at room temperature. The soaking solution was drained off and rinsed twice with distilled water, the soaked meal was dried and stored until used.

\section{Ethanol (70\%) treatment:}

Guar korma meal was sprayed by aqueous solution of ethanol at the rate of $10 \%(\mathrm{v} / \mathrm{w})$, then stored in plastic containers for 21 days at room temperature. The treated GKM was aerated, then ground to pass a 2 mm screen as described by Tasneem and Subramanian (1990).

\section{Lactic acid bacteria (LAB) treatment:}

Guar korma meal was treated with pioneer brand inoculants supplied by pioneer Hi-Bred international, Inc. at rate of $1 \mathrm{~g} / 100 \mathrm{~kg}$ GKM, stored in plastic containers for 21 days at room temperature, then dried to reach about $6 \%$ moisture and was ground to pass a $2 \mathrm{~mm}$ screen.

\section{Anti-nutritional compounds analysis:}

Approximately $200 \mathrm{mg}$ (DM) of ground samples of Guar korma meal was extracted in $10 \mathrm{ml}$ of aqueous acetone $(7: 3 \mathrm{v} / \mathrm{v})$ in a water bath maintained at $39-40 \circ \mathrm{C}$ for $90 \mathrm{~min}$ (Makkar, 2000). Saponnins were extracted and isolated according to Ahmad et al. (1990). Quantitative estimation of tannin for each sample was determined according to Makkar, (2000). Total phenolic components were assayed by FolinCiocalteu-reagent $2 \mathrm{~N}$ (Sigma®-Aldrich, El-Safua Co., Alexandria, Egypt) based on known concentrations of tannic acid as the calibration curve (Sigma ${ }^{\circledR}-$ Aldrich) according to Makkar and Becker 
(1993). Phytic acid concentration was determined by a colorimetric procedure described by Vairtrash and Laptera (1988). The trypsin inhibitor activity was determined by the method of Smith et al. (1980).

Six total mixed rations (TMR's) were formulated to be isonitrogenous and isoenergetic as follow 1) without GKM (control) (TMR), 2) with 10\% untreated GKM (TMRU), 3) with 10\% heated GKM (TMRH), 4) with 10\% soaking GKM (TMRS), 5) with 10\% GKM treated with ethanol (TMRE) and 6) with 10\% GKM treated with lactic acid bacteria (TMRB). Compositions and chemical analysis of the tested TMR's are presented in Table (1) and Table (2), respectively.

Table (1): Feed ingredients (\%) of the experimental total mixed rations (on dry matter basis).

\begin{tabular}{lcccccc}
\hline Feed ingredients, $\%$ & TMR & TMRU & TMRH & TMRS & TMRE \\
& TMRB & & & & & \\
\hline Yellow corn & 32 & 40 & 40 & 40 & 40 & 40 \\
Soybean meal & 14 & 5 & 5 & 5 & 5 & 4 \\
Wheat bran & 15 & 6 & 6 & 6 & 6 & 7 \\
Untreated guar korma meal & - & 10 & - & - & - & - \\
Guar korma meal treated with heat & - & - & 10 & - & - & - \\
Guar korma meal treated with soaking & - & - & - & 10 & - & - \\
Guar korma meal treated with ethanol & - & - & - & - & 10 & - \\
Guar korma meal treated with LAB & - & - & - & - & - & 10 \\
Chopped rice straw & 30 & 30 & 30 & 30 & 30 & 30 \\
Molasses & 5 & 5 & 5 & 5 & 5 & 5 \\
Limestone & 2 & 2 & 2 & 2 & 2 & 2 \\
Salt & 1.5 & 1.5 & 1.5 & 1.5 & 1.5 & 1.5 \\
Mineral premix & 0.5 & 0.5 & 0.5 & 0.5 & 0.5 & 0.5 \\
\hline
\end{tabular}

TMR: Total mixed ration (control).

TMRU: TMR containing untreated guar korma meal.

TMRH: TMR containing treated guar korma meal with heat.

TMRS: TMR containing treated guar korma meal with soaking.

TMRE: TMR containing treated guar korma meal with ethanol.

TMRB: TMR containing treated guar korma meal with lactic acid bacteria.

Table (2): Chemical analysis (\%) of the experimental total mixed rations (on dry matter basis).

\begin{tabular}{lcccccc}
\hline Item & TMR & TMRU & TMRH & TMRS & TMRE & TMRB \\
\hline OM & 89.17 & 89.54 & 89.57 & 89.58 & 89.51 & 89.46 \\
CP & 12.16 & 12.17 & 12.09 & 12.11 & 12.08 & 12.06 \\
CF & 14.92 & 14.42 & 14.44 & 14.32 & 14.40 & 14.15 \\
EE & 2.66 & 3.14 & 3.22 & 3.34 & 3.08 & 3.17 \\
NFE & 59.43 & 59.81 & 59.82 & 59.81 & 59.95 & 60.08 \\
Ash & 10.83 & 10.46 & 10.43 & 10.42 & 10.49 & 10.54 \\
\hline
\end{tabular}

\section{Digestibility and nitrogen balance trials:}

Six digestibility and nitrogen balance trials were carried out using three rams $(44 \pm 1.30 \mathrm{~kg}$, in average) for each TMR. Each trial lasted for four weeks; the first three weeks were as a preliminary period, followed by one week for feces and urine collection. Sheep were fed twice daily at 8 am and 4 pm. Water was offered freely. Each animal was offered the tested TMR's according to NRC (1994). Chemical analysis of feeds, feces and urine were determined according to A.O.A.C (1995) methods.

\section{Rumen fermentation and In situ trials:}

Three ruminally-canulated Barki ewes were used for testing the rumen fermentation and in situ trials for each TMR. Rumen samples were withdrawn before feeding and 1, 3 and $6 \mathrm{~h}$ after feeding for in vitro incubation using the zero rate techniques as described by Carrol and Hungate (1954). Ruminal $\mathrm{pH}$ value measured using digital $\mathrm{pH}$ meter (Orian 680). Ammonia-N was carried out using MgO distillation method (AL-Rabbat et al., 1971). Total VFA's were determined by steam distillation as described by Warner (1964). Rumen volume was determined by colorimetric method of cr-EDTA before, 3 and $6 \mathrm{~h}$ after feeding (El-Shazly et al., 1976). Total bacteria count was carried out according to Difco (1984). Count of protozoa was carried out according to Galyean (1989) based on the use of a hemacytometer (Hausser Scientific, Horsham, PA). The microbial protein synthesis (g MP/day) in the rumen of sheep fed the experimental TMR's was calculated using the model equation by Borhami et al. (1992) as follow: g 
$\mathrm{MP} /$ day $=$ mole VFA produced $/$ day $\times 2 \times 13.48 \times 10.5 \times 6.25 / 100$ where one mole VFA yield about 2 mole ATP (Walker, 1965), one mole ATP produce $13.48 \mathrm{Y}_{\text {ATP }}$ (g DM microbial cell) (Borhami et al., 1979), N \% of dry microbial cell = 10.5 (Hungate, 1965). Nylon bags technique (Mehrez and Ørskov, 1977) was used to determine DM and CP degradability for TMR's. Two polyester bags $(7 X 15 \mathrm{~cm})$ with pore size of $45 \mu \mathrm{m}$ were used for each incubation time. Approximately $5 \mathrm{~g}$ of air-dried ration (ground to 2 $\mathrm{mm}$ ) were placed in each bag. Bags were incubated in the rumen of each sheep and withdrawn after 3, 6, $12,24,48,72$ and $96 \mathrm{~h}$. After the bags were withdrawn from the rumen, they were rinsed in tap water until the water became clear, then they were squeezed gently. Microorganisms attached to the residual sample were eliminated by freezing at $-20^{\circ} \mathrm{C}$ (Kamel et al., 1995). Zero-time washing losses (a) were determined by washing 2 bags in running water for $15 \mathrm{~min}$. The degradation kinetics of DM and CP were estimated (in each bag) by fitting the disappearance values to the equation $P=a+b\left(1-e^{-c t}\right)$ as proposed by Ørskov and McDonald (1979), where P represents the disappearance after time t. Least-squares estimated soluble fractions are defined as the rapidly degraded fraction (a), slowly degraded fraction (b) and the rate of degradation (c), respectively. The effective degradability (ED) for tested TMR were estimated from the equation cited by McDonald (1981), where $\mathrm{ED}=\mathrm{a}+\mathrm{bc} /(\mathrm{c}+\mathrm{k}), \mathrm{k}$ is the out flow rate.

\section{Growth performance trials:}

Thirty male growing lambs, with an average initial live body weight $21.4 \pm 1.20 \mathrm{~kg}$ and $4-5$ months of age were used. Lambs were randomly divided into six similar groups according to their body weights (five lambs in each TMR). Animals were weighed biweekly. They were fed the six TMR's in group feeding in tow equal meals / day ( 8 am and 4 pm) for 120 days. All lambs were offered TMR's according to NRC (1994).Water were offered freely.Feed intake was daily recorded and then feed conversion was calculated.

\section{Blood analyses:}

Blood samples were taken every four weeks before morning feeding from the external jugular vein of each male lamb. Serum was obtained by centrifugation of blood at $4000 \mathrm{rpm}$ for $15 \mathrm{~min}$ and was stored at $-18^{\circ} \mathrm{C}$ until the time of analysis. Various chemical parameters were calorimetrically determined using commercial kits; following the same steps as described by manufactures. Glucose concentration was determined according to Trinder (1969); total proteins was measured as described by the Biuret method according to Henry et al. (1974); albumin (A) was assayed according to Doumas et al. (1971); Globulin (G) was calculated by subtracting the albumin value from total protein value; urea was detected according to Berthelot (1959); creatinine was measured according to Faulkner and King (1976); Cholesterol was detected according to Stein (1986). Liver function was assessed by measuring the activities of aspartate aminotransferase (AST) and alanine aminotransferase (ALT) according to Reitman and Frankel (1957).

\section{Statistical analyses:}

Collected data were statistically analyzed using the method of least squares analysis of variance using General Linear Models (GLM) procedure (SAS, 2000). The model used was as follow:

$\mathrm{Y}_{\mathrm{ij}}=\mu+\mathrm{T}_{\mathrm{i}}+\mathrm{e}_{\mathrm{ij}}$

Where: $Y_{i j}=$ an observation taken on the $j^{\text {th }}$ individual, $\mu=$ overall mean, $T_{i}=$ a fixed effect of the $i^{\text {th }}$ treatment ( $\mathrm{i}=1$ to 6$), \mathrm{e}_{\mathrm{ij}}=\mathrm{A}$ random error assumed to be normally distributed with mean $=0$ and variance $=\sigma^{2}$. Significant differences among means were separated using LSD test according to Duncan (1955).

\section{RESULTS AND DISCUSSION}

\section{Chemical analyses of untreated and treated Guar korma meal:}

The chemical analysis of GKM used in this experiment is presented in Table (3). GKM had a high $\mathrm{CP}$ content so; it can be used as good protein source for animal feed. Findings of the present study were supported by Mishra et al. (2013) and Sharif et al. (2014). It had higher contents of crude fiber $8.79 \%$ and ether extract $6.34 \%$ if it compared with soybean meal (5.34 and 1.35\%, respectively), which is consistent with the finding of Mathur and Mathur (1989). Treatment GKM with LAB resulted in an increase in CP content by about $4 \%$, while it was decreased by about $2 \%$ with heating and ethanol treatments. On the other hand, CF content was decreased by about $34 \%$ and $7 \%$ with treatment GKM with LAB and soaking, respectively. Other treatments had quite similar CF content. Ash content was increased by about 10 and 
5\% with treatment GKM with LAB and ethanol, respectively, while it was decreased by about $4 \%$ in soaking treatment.

\section{Concentration of anti-nutritive compounds:-}

The screening of anti-nutritive compounds in the untreated and treated Guar korma meal revealed the presence of saponins; tannins; poly phenolic components; phytate and trypsin inhibitor. Data in Table (3) showed that all treatments had positive effect in decreasing concentration of anti-nutritive compounds. These considered as inhibitors and negative effect compounds on appetite of livestock feeds and reduce the nutrient utilization and/or food intake (Shanthakumari et al., 2008; Soetan and Oyewol, 2009 and Gemede and Ratta, 2014). Heat treatment decreased the concentration of saponins; tannins; poly phenolic components; phytate and trypsin inhibitor by about 49, 47, 57, 51 and 69\%, respectively. Ahmed et al. (2006) reported that moist heating of guar seed has an effect on lowering levels of toxicants. Nidhina and Muthukumar (2015) when compared to the guar churi and guar korma fractions found that both showed the presence of different antinutritional factors, such as trypsin inhibitor, phytate, tannins and saponins, heat treatments significantly reduced these antinutritional factors and functional properties of different fractions of industrial guar meal. Soaking was found to be less effect in improving GKM as it decreased the concentration of saponins; tannins; poly phenolic components; phytate and trypsin inhibitor by about 43, 42, 53, 44 and 41\%, respectively. Shi et al. (2009) showed that the soaking times and seed-to-water ratios significantly influenced the quantity of saponins leached out from the beans' matrix during the soaking processes. Ethanol treatment decreased the concentration of saponins; tannins; poly phenolic components; phytate and trypsin inhibitor by about 70, 59, 64, 81 and 71\%, respectively. Also, Tasneem and Subramanian (1990) noticed that the free poly phenol content was lower for detoxified guar meal by aqueous alcohol extracted. Incubation of GKM with LAB was found to be an effective method in improving GKM as it decreased concentration of saponins; tannins; poly phenolic components; phytate and trypsin inhibitor by about $74,62,71,83$ and $72 \%$, respectively. So, LAB had more influence in that respect, whereas, it resulted in reduction of toxic and anti-nutritional than the critical percentages compound. These could be explained by the role of LAB in solubilization of such chemicals in the fermentation process (Rattanachaikunsopon and Phumkhachorn, 2010).

Table (3): Chemical analysis (\%) and concentration of anti nutritive compounds (on dry matter basis) of treated and untreated guar korma meal.

\begin{tabular}{|c|c|c|c|c|c|}
\hline \multirow{2}{*}{ Item } & \multirow{2}{*}{$\begin{array}{l}\text { Untreated } \\
\text { GKM }\end{array}$} & \multicolumn{4}{|c|}{ Treated } \\
\hline & & GKMH & GKMS & GKME & GKMB \\
\hline \multicolumn{6}{|l|}{ Chemical analysis (\%): } \\
\hline $\mathrm{OM}$ & 93.87 & 93.98 & 94.13 & 93.57 & 93.26 \\
\hline $\mathrm{CP}$ & 43.26 & 42.48 & 42.71 & 42.43 & 44.97 \\
\hline $\mathrm{CF}$ & 8.79 & 9.03 & 8.14 & 8.58 & 5.84 \\
\hline $\mathrm{EE}$ & 6.34 & 7.11 & 8.07 & 5.67 & 6.42 \\
\hline NFE & 35.48 & 35.36 & 35.21 & 36.89 & 36.03 \\
\hline Ash & 6.13 & 6.02 & 5.87 & 6.43 & 6.74 \\
\hline \multicolumn{6}{|c|}{ Concentration of anti nutritive compounds: } \\
\hline Saponins $(\%)$ & 8.840 & 4.516 & 5.022 & 2.673 & 2.324 \\
\hline Tannins $(\%)$ & 1.760 & 0.938 & 1.102 & 0.714 & 0.676 \\
\hline Poly phenolic (\%) & 2.980 & 1.281 & 1.401 & 1.072 & 0.864 \\
\hline Phytic acid (\%) & 0.535 & 0.262 & 0.302 & 0.103 & 0.092 \\
\hline Trypsin Inhibitor Activities TIU/g* & 3520 & 1085 & 2074 & 1021 & 1003 \\
\hline
\end{tabular}

TIU/g* = trypsin inhibitor units per gram.

GKM : Untreated guar korma meal.

GKMH: Treated guar korma meal with heat.

GKMS: Treated guar korma meal with soaking.

GKME: Treated guar korma meal by ethanol.

GKMB: Treated guar korma meal with lactic acid bacteria.

\section{Digestibility and nitrogen balance trials:}

Except for NFE digestibility the highest $(\mathrm{P}<0.05)$ digestibility value of nutrients was recorded for TMR contained LAB treated GKM followed by TMR contained ethanol treated GKM, while the lowest value of DM, OM and CP digestibility's were obtained for TMR contained untreated GKM in comparison with control values (Table 4). The digestibility of CP for TMR contained untreated GKM was lower than digestibility of $\mathrm{CP}$ for TMR's contained treated GKM as a result to the high content of trypsin inhibitor 
and other anti-nutritional compounds on untreated GKM. Soaking of GKM showed less effect in improving nutrients digestibility compared to other treatments. However, these results were reflected on dry matter intake and feeding values of experimental rations. Sheep fed TMR contained LAB treated GKM was recorded highest $(\mathrm{P}<0.05)$ daily feed intake followed by ethanol treated GKM, while, TMR contained heating treated GKM and control were showed quite the same daily feed intake. However, TMR's contained untreated GKM and soaking treated GKM were recorded less daily feed intake. The improvement in nutrients digestibility followed the biological and chemical treatments could be a result of better feed intake and nutritive value. The presence of saponins, glycosides, tannins, alkaloids, conjugates of protein with phytin or hemicellulose and substances inhibiting the action of digestive enzyme trypsin in different food legumes adversely affect their digestibility as these substances are antagonistic to digestion (Gupta, 1987). Saponins, in high concentrations, impart a bitter taste and astringency in dietary plants and reduce palatability of livestock feeds (Gemede and Ratta, 2014). In addition, saponins were found to reduce the bioavailability of nutrients and decrease enzyme activity and it affect protein digestibility by inhibit various digestive enzymes such as trypsin and chymotrypsin (Liener, 2003). Some authors considered saponins as a toxic compound. However, saponins contents below 3\% reported by Kumar (1991) which could be responsible for cattle weight losses when they grazed on alfonibrilla (Drymaria arenaroides). Gemede and Ratta (2014) concluded that some antinutritional factors as well as their breakdown products may possess beneficial health effects if present in small amounts. The TDN and DCP values for LAB treated GKM containing ration were recorded significantly the highest value (Table 5). Lowest values were obtained with untreated GKM containing ration. Less $(\mathrm{P}<0.05) \mathrm{N}$-intake was noticed for sheep fed untreated GKM containing ration, this could be due to the effect of the anti-nutritional substances content of GKM in depressing feed intake. Nitrogen balance showed the same trend. Biological value of dietary-N was higher for LAB treated GKM.

Table (4): Digestibility coefficients of the experimental TMR's fed to sheep.

\begin{tabular}{ccccccccc}
\hline Digestibility & \multicolumn{7}{c}{ Experimental TMR's } \\
\cline { 2 - 8 } coefficients (\%) & TMR & TMRU & TMRH & TMRS & TMRE & TMRB & SEM & Sig. \\
\hline DM & $61.05^{\mathrm{b}}$ & $58.65^{\mathrm{c}}$ & $60.79^{\mathrm{b}}$ & $59.55^{\mathrm{bc}}$ & $63.53^{\mathrm{a}}$ & $64.04^{\mathrm{a}}$ & 0.45 & $*$ \\
OM & $65.85^{\mathrm{abc}}$ & $62.88^{\mathrm{c}}$ & $64.76^{\mathrm{bc}}$ & $63.82^{\mathrm{c}}$ & $67.60^{\mathrm{ab}}$ & $68.31^{\mathrm{a}}$ & 0.58 & $*$ \\
CP & $59.19^{\mathrm{c}}$ & $57.14^{\mathrm{d}}$ & $58.98^{\mathrm{c}}$ & $57.94^{\mathrm{cd}}$ & $63.50^{\mathrm{b}}$ & $65.25^{\mathrm{a}}$ & 0.74 & $*$ \\
CF & $58.35^{\mathrm{c}}$ & $57.78^{\mathrm{c}}$ & $60.92^{\mathrm{b}}$ & $60.08^{\mathrm{bc}}$ & $62.29^{\mathrm{b}}$ & $64.90^{\mathrm{a}}$ & 0.49 & $*$ \\
EE & $66.13^{\mathrm{b}}$ & $67.70^{\mathrm{ab}}$ & $67.52^{\mathrm{ab}}$ & $66.16^{\mathrm{b}}$ & $70.75^{\mathrm{a}}$ & $70.81^{\mathrm{a}}$ & 0.61 & $*$ \\
NFE & 69.08 & 65.03 & 66.71 & 65.62 & 69.54 & 69.59 & 0.66 & NS \\
\hline
\end{tabular}

$* P<0.05$ and N.S $=$ Not significant.

$a, b, c$, and $d$, means in the same row with different superscripts are significantly differ $(P<0.05)$.

SEM: standard error of mean; Sig.: significant.

Table (5): Dry matter intake (g/h/d), nutritive value and nitrogen utilization of the experimental TMR's fed to sheep.

\begin{tabular}{|c|c|c|c|c|c|c|c|c|}
\hline \multirow[t]{2}{*}{ Item } & \multicolumn{8}{|c|}{ Experimental TMR's } \\
\hline & TMR & TMRU & TMRH & TMRS & TMRE & TMRB & SEM & Sig. \\
\hline DMI $(\mathrm{g} / \mathrm{h} / \mathrm{d})$ : & $1239.7^{\mathrm{c}}$ & $1147.17^{\mathrm{d}}$ & $1223.19^{c}$ & $1198.50^{\mathrm{d}}$ & $1264.36^{b}$ & $1308.72^{\mathrm{a}}$ & 9.45 & $*$ \\
\hline Nutritive value: & & & & & & & & \\
\hline$(\mathrm{TDN} \%)$ & $60.91^{\mathrm{ab}}$ & $58.96^{\mathrm{b}}$ & $60.72^{\mathrm{ab}}$ & $59.99^{b}$ & $62.25^{\mathrm{ab}}$ & $63.91^{\mathrm{a}}$ & 0.52 & $*$ \\
\hline (DCP \%) & $7.20^{\mathrm{c}}$ & $6.95^{\mathrm{d}}$ & $7.13^{\mathrm{cd}}$ & $7.02^{\mathrm{cd}}$ & $7.63^{\mathrm{b}}$ & $7.87^{\mathrm{a}}$ & 0.08 & $*$ \\
\hline Nitrogen utilization: & & & & & & & & \\
\hline $\mathrm{N}$-intake $(\mathrm{g} / \mathrm{d})$ & $24.12^{\mathrm{ab}}$ & $22.34^{\mathrm{c}}$ & $23.66^{\mathrm{abc}}$ & $23.22^{\mathrm{bc}}$ & $24.44^{\mathrm{ab}}$ & $25.25^{\mathrm{a}}$ & 0.28 & $*$ \\
\hline $\mathrm{N}$ - absorbed (g/d) & $14.28^{c}$ & $12.77^{\mathrm{d}}$ & $13.95^{\mathrm{c}}$ & $13.45^{\mathrm{cd}}$ & $15.43^{\mathrm{b}}$ & $16.48^{\mathrm{a}}$ & 0.32 & $*$ \\
\hline N-balance $(\mathrm{g} / \mathrm{d})$ & $5.35^{\mathrm{bc}}$ & $4.51^{\mathrm{c}}$ & $5.14^{\mathrm{bc}}$ & $4.92^{c}$ & $5.95^{\mathrm{ab}}$ & $6.58^{\mathrm{a}}$ & 0.19 & $*$ \\
\hline $\begin{array}{c}\text { N-balance as } \% \text { of } \\
\text { N intake }\end{array}$ & $22.10^{\mathrm{ab}}$ & $20.26^{\mathrm{b}}$ & $21.75^{\mathrm{b}}$ & $21.22^{\mathrm{b}}$ & $24.39^{\mathrm{ab}}$ & $26.08^{\mathrm{a}}$ & 0.65 & $*$ \\
\hline $\begin{array}{c}\text { N-balance as } \% \text { of } \mathrm{N}- \\
\text { abso. }\end{array}$ & $37.29^{\mathrm{ab}}$ & $35.47^{\mathrm{b}}$ & $36.85^{\mathrm{b}}$ & $36.63^{\mathrm{b}}$ & $38.59^{\mathrm{ab}}$ & $39.97^{\mathrm{a}}$ & 0.68 & * \\
\hline
\end{tabular}

$a, b, c$, and $d$, means in the same row with different superscripts are significantly differ $(P<0.05)$.

SEM: standard error of mean; Sig.: significant. 


\section{Ruminal fermentation:}

Ruminal $\mathrm{pH}$ values were not significantly affected by the dietary TMR's (Table 6). This was agreed with the finding of Bargo et al. (2001) who reported that ruminal $\mathrm{pH}$ was not affected by level or source of protein. The rumen $\mathrm{pH}$ values in the present study are within the normal range reported for sheep, which is suitable for maximal cellulytic activity and microbial protein synthesis (Salem, 2006). The overall mean of $\mathrm{NH}_{3}-\mathrm{N}$ concentration in the rumen of sheep fed heated GKM was lower $(\mathrm{P}<0.05)$ than other TMR's. The effect could be generally caused by Millard reaction as an irreversible binding between aldehyde groups of the sugar and free amino acid groups. As a result, protection of protein by heat is often accompanied by corresponding reduction in digestibility. Ruminal $\mathrm{NH}_{3}-\mathrm{N}$ concentration values revealed that it was sufficient for microbial growth as described by Lu et al. (1990). Both GKMH and GKME containing TMR's had quiet similar rate of production. TMR contained GKMB has the higher (P $<0.05)$ rate of $\mathrm{NH}_{3}-\mathrm{N}$ production. While those containing control; GKMU and GKMS were showed the lower rate of $\mathrm{NH}_{3}-\mathrm{N}$ production. Volatile fatty acids concentrations, in the present study were lies in range suggested by Bruggeman and Giescke (1976). This means that the energy and ammonia releases are nearly synchronized and enhance microbial protein production. High VFA's concentration and rate of production $(\mathrm{P}<0.05)$ for biological treatment may be related to the more utilization of the dietary energy and positive fermentation in the rumen. Lowest total bacteria and protozoa counts were recorded with UGKM containing ration. This finding was agreed with Avato et al. (2006); Ma et al. (2007); Hassan et al. (2010) and Wina (2012) they reported that various biological effects of saponins and phenolic component are antibacterial and antiprotozoal. Lila et al. (2005) cited that the saponins is also inhibitory for some of the rumen ciliate protozoa and bacteria. However, saponins below critical level have received considerable attention due to their beneficial effects on animal health (Hassan et al., 2013). Thalib et al. (1996) studied the effect of saponins of Sapindus rarak fruit on rumen microbes of sheep and reported that the methanol extract of seeds caused a 57\% reduction in the number of protozoa and $69 \%$ increase in bacterial population which resulted in improved feed conversion efficiency and better gain in body weight of the animals. The overall mean revealed that a high $(\mathrm{P}<0.05)$ rate of out flow from the rumen was obtained with sheep fed TMR; TMRU and TMRS compared to other three TMR's which showed almost similar rate of out flow. The rate of out flow observed in this study with TMRB could be considered as suitable rate of out flow for efficient MP synthesis. There are significant $(\mathrm{P}<0.05)$ increases in the microbial protein synthesis when GKM was treated with lactic acid bacteria (Table 6). It significantly increases the calculated flow of microbial nitrogen from the rumen. Nkosi et al. (2011) and Basso et al. (2014) reported an increase in nitrogen retention and protein flow from the rumen in sheep fed biological treated $(\mathrm{LAB})$ rations. However, biological treatment could be reasonably for good MN synthesis in the rumen. Subsequently, the limitation upon the cellulolytic bacteria could influence on fiber fermentation, digesta outflow, and feed intake (Gilbery et al. 2006).Ultimately; this alteration of bacterial functionality may affect the amount of energetic substrates (VFA) and AA available to the ruminant animal.

Table (6): Rumen parameters of sheep fed the experimental TMR's.

\begin{tabular}{|c|c|c|c|c|c|c|c|c|}
\hline \multirow[t]{2}{*}{ Item } & \multicolumn{8}{|c|}{ Experimental TMR's } \\
\hline & TMR & TMRU & TMRH & TMRS & TMRE & $\begin{array}{c}\text { TMR } \\
\text { B }\end{array}$ & SEM & Sig. \\
\hline $\mathrm{pH}$ value & 6.41 & 6.38 & 6.33 & 6.36 & 6.35 & 6.26 & 0.12 & $\mathrm{NS}$ \\
\hline $\begin{array}{l}\mathrm{NH}_{3}-\mathrm{N} \\
\text { concentration }(\mathrm{mg} / 100 \mathrm{ml})\end{array}$ & $13.63^{\mathrm{a}}$ & $13.61^{\mathrm{a}}$ & $13.08^{b}$ & $13.49^{\mathrm{a}}$ & $13.43^{\mathrm{a}}$ & $13.71^{\mathrm{a}}$ & 0.09 & $*$ \\
\hline $\begin{array}{l}\text { Rate of } \mathrm{NH}_{3}-\mathrm{N} \\
\text { production }(\mathrm{g} / 100 \mathrm{ml} / \mathrm{h})\end{array}$ & $2.83^{c}$ & $2.91^{\mathrm{c}}$ & $3.29^{b}$ & $2.96^{\mathrm{c}}$ & $3.42^{\mathrm{b}}$ & $3.68^{\mathrm{a}}$ & 0.08 & $*$ \\
\hline $\begin{array}{l}\text { VFA's } \\
\text { concentration }(\mathrm{meq} / 100 \mathrm{ml})\end{array}$ & $11.47^{\mathrm{c}}$ & $10.67^{\mathrm{d}}$ & $12.14^{\mathrm{ab}}$ & $11.31^{\mathrm{c}}$ & $12.34^{\mathrm{ab}}$ & $12.66^{\mathrm{a}}$ & 0.19 & $*$ \\
\hline $\begin{array}{l}\text { Rate of VFA's } \\
\text { production }(\mathrm{meq} / 100 \mathrm{ml} / \mathrm{h})\end{array}$ & $3.86^{\mathrm{d}}$ & $3.19^{\mathrm{e}}$ & $4.18^{c}$ & $3.83^{\mathrm{d}}$ & $4.47^{b}$ & $4.76^{\mathrm{a}}$ & 0.11 & $*$ \\
\hline $\begin{array}{l}\text { Total bacteria counts, } \\
\times 10^{8} \mathrm{cfu} / \mathrm{ml}\end{array}$ & $1.28^{b}$ & $1.17^{\mathrm{c}}$ & $1.28^{\mathrm{b}}$ & $1.26^{\mathrm{b}}$ & $1.37^{\mathrm{a}}$ & $1.39^{\mathrm{a}}$ & 0.02 & $*$ \\
\hline $\begin{array}{l}\text { Total protozoa counts, } \\
\times 10^{6} \mathrm{cfu} / \mathrm{ml}\end{array}$ & $4.84^{\mathrm{a}}$ & $3.96^{\mathrm{c}}$ & $4.19^{\mathrm{b}}$ & $4.15^{\mathrm{b}}$ & $4.17^{\mathrm{b}}$ & $4.13^{\mathrm{b}}$ & 0.07 & $*$ \\
\hline Rumen volume (L) & $3.34^{\mathrm{d}}$ & $3.19^{\mathrm{d}}$ & $3.65^{\mathrm{c}}$ & $3.32^{\mathrm{d}}$ & $3.88^{b}$ & $4.06^{\mathrm{a}}$ & 0.08 & $*$ \\
\hline Rate of out flow (\%h) & $6.22^{\mathrm{a}}$ & $6.49^{\mathrm{a}}$ & $5.56^{\mathrm{b}}$ & $6.27^{\mathrm{a}}$ & $5.43^{\mathrm{b}}$ & $5.21^{\mathrm{b}}$ & 0.13 & $*$ \\
\hline $\begin{array}{l}\text { Microbial Protein Synthesis, } \\
\text { (g/head/day) }\end{array}$ & $67.22^{\mathrm{d}}$ & $54.16^{\mathrm{e}}$ & $78.99^{c}$ & $65.37^{d}$ & $89.32^{\mathrm{b}}$ & $\begin{array}{c}100.6 \\
2^{\mathrm{a}}\end{array}$ & 3.83 & $*$ \\
\hline
\end{tabular}




\section{Degradation kinetics:}

Estimated ruminal degradation kinetics constants ( $a, b$ and $c$ ) fitted with rates of DM and CP disappearance for experimental TMR's are presented in Table (7).

Table (7): Degradation kinetics of DM and CP for total mixed rations in sheep fed the experimental TMR's.

\begin{tabular}{ccccccccc}
\hline \multirow{2}{*}{ Item } & \multicolumn{7}{c}{ Experimental TMR's } \\
\cline { 2 - 8 } & TMR & TMRU & TMRH & TMRS & TMRE & TMRB & SEM & Sig. \\
\hline & & & & DM & & & & \\
a & $23.16^{\mathrm{b}}$ & $21.08^{\mathrm{c}}$ & $23.29^{\mathrm{b}}$ & $23.24^{\mathrm{b}}$ & $24.85^{\mathrm{a}}$ & $25.92^{\mathrm{a}}$ & 0.29 & $*$ \\
$\mathrm{~b}$ & $46.92^{\mathrm{b}}$ & $44.16^{\mathrm{c}}$ & $47.13^{\mathrm{b}}$ & $47.28^{\mathrm{b}}$ & $49.17^{\mathrm{a}}$ & $49.83^{\mathrm{a}}$ & 0.74 & $*$ \\
$\mathrm{c}$ & $0.039^{\mathrm{b}}$ & $0.036^{\mathrm{c}}$ & $0.040^{\mathrm{b}}$ & $0.039^{\mathrm{b}}$ & $0.042^{\mathrm{a}}$ & $0.042^{\mathrm{a}}$ & 0.002 & $*$ \\
EDDM & $43.71^{\mathrm{b}}$ & $39.56^{\mathrm{c}}$ & $44.23^{\mathrm{b}}$ & $44.19^{\mathrm{b}}$ & $47.29^{\mathrm{a}}$ & $48.65^{\mathrm{a}}$ & 0.86 & $*$ \\
& & & & CP & & & & \\
$\mathrm{a}$ & $18.60^{\mathrm{a}}$ & $19.62^{\mathrm{b}}$ & $19.49^{\mathrm{b}}$ & $20.66^{\mathrm{a}}$ & $20.69^{\mathrm{a}}$ & $20.83^{\mathrm{a}}$ & 0.14 & $*$ \\
$\mathrm{~b}$ & $53.89^{\mathrm{a}}$ & $49.38^{\mathrm{c}}$ & $49.04^{\mathrm{c}}$ & $49.88^{\mathrm{bc}}$ & $51.02^{\mathrm{b}}$ & $51.36^{\mathrm{b}}$ & 0.41 & $*$ \\
$\mathrm{c}$ & $0.055^{\mathrm{b}}$ & $0.0500^{\mathrm{c}}$ & $0.0500^{\mathrm{c}}$ & $0.0520^{\mathrm{bc}}$ & $0.053^{\mathrm{bc}}$ & $0.059^{\mathrm{a}}$ & 0.001 & $*$ \\
EDCP & $46.83^{\mathrm{b}}$ & $44.31^{\mathrm{c}}$ & $43.99^{\mathrm{c}}$ & $46.08^{\mathrm{bc}}$ & $46.94^{\mathrm{b}}$ & $48.63^{\mathrm{a}}$ & 0.48 & $*$ \\
\hline$* P<0.05$. & & & & & & & &
\end{tabular}

$a, b$ and $c$, means in the same row with different superscripts are significantly differ $(P<0.05)$.

SEM: standard error of mean; Sig.: significant.

a: soluble fraction (\%).

b: potentially degradable fraction (\%).

c: rate of degradation ( $\% h-1)$.

$E D$ : effective degradability $=a+[b c / c+k]$, where $k$ is passage rate.

EDDM: effective degradability of dry matter.

EDCP: effective degradability of crude protein.

It illustrated that washing loss fraction "a", degradable fraction "b", rate of degradation "c" and effective degradability " ED " of DM for TMR's were less $(\mathrm{P}<0.05)$ in untreated GKM compared with the control TMR. While it was higher $(\mathrm{P}<0.05)$ for TMR's containing biologically and chemically treated GKM as compared with untreated one and other TMR's. As a result of these treatments increased DMD than other treatments. The decrease of degradability of TMR containing untreated GKM may be due to the negative effect of saponnins and trypsin inhibitor as well as other anti-nutritional on ruminal microorganisms. This finding is agreed with Abo El-Fadel et al. (2011) who concluded that the decrease of degradability of CFM's containing untreated Jatropha Meal (JM) may be due to the negative effect of trypsin inhibitor and lectin on ruminal microorganisms. Also, Rakshit et al. (2008) concluded that trypsin inhibitor content of JM as well as other anti-nutritional compounds are affecting digestibility. However, ruminal degradation constants ( $\mathrm{a}, \mathrm{b}$ and $\mathrm{c}$ ) and effective degradability "ED" of CP for TMR's were less $(\mathrm{P}<0.05)$ in untreated GKM and heated GKM. Salehpour and Qazvinian (2011) reported that decreasing blood urea nitrogen with increasing guar meal percentage of diets may have affected low rumen degradable $\mathrm{CP}$ of guar meal, concentration ammonia in rumen or decrease microbial protein synthesis. On the mean time, the degradability of $\mathrm{CP}$ with ethanol and bacteria treatments were higher than heat treatment, which may be as a result to the over protection with heat treatment. Lower washing loss fraction "a", degradable fraction "b", rate of degradation "c" and effective degradability " ED " were noticed with untreated GKM containing ration for DM and CP degradation compared to the control and other experimental TMR's. These could be related to the less digestibilities of them in the rumen, and may be to the effect of anti-nutritive substances, which lead to less feed intake as well.

\section{Growth performance:}

The highest final weight, total gain and daily gain were recorded with TMR contained LAB treated GKM .While the lowest values were recorded with TMR contained untreated GKM (Table 8). Huston and Shelton (1971) reported that where raw guar meal (RGM) was included in the ration of lambs, performance was significantly depressed. Palatability may have been reduced due to the strong odor of RGM, but it is likely that also other factors were involved and contributed to the observed reduction in feed intake. There was a tendency for the lambs fed guar meal to poor performance especially early in the feeding period. Results of feed intake showed that with heating, chemically and biologically treated GKM and control significantly increased compared with untreated GKM containing ration, while no differences 
between TMRU and TMRS. Best feed conversion was observed with TMR contained LAB treated GKM, followed by those treated with ethanol, then heating. Total mixed rations containing heating, soaking, ethanol and LAB treated GKM were the cheaper than the control. Sharif et al. (2014) found that guar (GM) meal based diet was more economical than diets containing cotton seed cake (CSC) and CSC+GM. Mahdavi et al. (2010) pointed out that replacing protein sources with cheaper guar meal resulted in better economic efficiency. The economic cash return (L.E/h/d) was more pronounced with TMR contained LAB treated GKM than other rations (Table 9).

Table (8): Effect of feeding experimental TMR's on lamb performance and feed efficiency.

\begin{tabular}{lcccccccc}
\hline Item & \multicolumn{7}{c}{ Experimental } & TMR's \\
\cline { 2 - 8 } & TMR & TMRU & TMRH & TMRS & TMRE & TMRB & SEM & Sig. \\
\hline Initial BW(kg/h) & 21.50 & 21.60 & 21.30 & 21.40 & 21.50 & 21.30 & 0.04 & NS \\
Final BW(kg/h) & $36.74^{\mathrm{bc}}$ & $35.28^{\mathrm{d}}$ & $36.72^{\mathrm{bc}}$ & $35.92^{\mathrm{cd}}$ & $37.82^{\mathrm{ab}}$ & $38.82^{\mathrm{a}}$ & 0.32 & $*$ \\
Total gain (g/h) & $15.24^{\mathrm{c}}$ & $13.68^{\mathrm{d}}$ & $15.42^{\mathrm{c}}$ & $14.52^{\mathrm{cd}}$ & $16.32^{\mathrm{b}}$ & $17.52^{\mathrm{a}}$ & 0.79 & $*$ \\
Average daily gain & $127.00^{\mathrm{c}}$ & $114.00^{\mathrm{d}}$ & $128.50^{\mathrm{c}}$ & $121.00^{\mathrm{cd}}$ & $136.00^{\mathrm{b}}$ & $146.00^{\mathrm{a}}$ & 2.69 & $*$ \\
(g/h) & & & & & & & & \\
Feed Intake(g/h/d) & & & & & & & \\
DMI & $981.00 \mathrm{~b}^{\mathrm{c}}$ & $916.00^{\mathrm{d}}$ & $958.00^{\mathrm{c}}$ & $929.00^{\mathrm{d}}$ & $987.00^{\mathrm{b}}$ & $1015.00^{\mathrm{a}}$ & 8.69 & $*$ \\
TDNI & $597.53^{\mathrm{c}}$ & $540.07^{\mathrm{f}}$ & $581.70^{\mathrm{d}}$ & $557.59^{\mathrm{e}}$ & $614.41^{\mathrm{b}}$ & $648.69^{\mathrm{a}}$ & 8.85 & $*$ \\
DCPI & $70.63^{\mathrm{c}}$ & $63.66^{\mathrm{e}}$ & $68.31^{\mathrm{d}}$ & $65.22^{\mathrm{e}}$ & $75.31^{\mathrm{b}}$ & $79.88^{\mathrm{a}}$ & 1.38 & $*$ \\
Feed Conversion & & & & & & & & \\
Kg DMI/ Kg gain & $7.73^{\mathrm{ab}}$ & $8.05^{\mathrm{a}}$ & $7.47^{\mathrm{b}}$ & $7.68^{\mathrm{ab}}$ & $7.26^{\mathrm{bc}}$ & $6.96^{\mathrm{c}}$ & 0.11 & $*$ \\
Kg TDNI/ Kg gain & $4.71^{\mathrm{a}}$ & $4.74^{\mathrm{a}}$ & $4.53^{\mathrm{b}}$ & $4.61^{\mathrm{ab}}$ & $4.52^{\mathrm{b}}$ & $4.45^{\mathrm{b}}$ & 0.10 & $*$ \\
\hline
\end{tabular}

$* P<0.05$ and N.S $=$ Not significant.

$a, b, c$, d,e and $f$, means in the same row with different superscripts are significantly differ $(P<0.05)$.

SEM: standard error of mean; Sig.: significant.

DMI: dry matter intake.

TDNI: total digestible nutrients intake.

DCPI: digestible crud protein intake.

Table (9): Effect of incorporation of guar korma meal on the economic efficiency of growing Barki lambs.

\begin{tabular}{lcccccc}
\hline \multirow{2}{*}{ Item } & \multicolumn{5}{c}{ Experimental TMR's } \\
\cline { 2 - 6 } & TMR & TMRU & TMRH & TMRS & TMRE & TMRB \\
\hline Average daily feed cost (L.E) & 1.67 & 1.43 & 1.51 & 1.47 & 1.56 & 1.58 \\
Price of daily gain(L.E) & 4.19 & 3.76 & 4.24 & 3.99 & 4.49 & 4.82 \\
Economical return((L.E /h/d) & 2.52 & 2.33 & 2.73 & 2.52 & 2.93 & 3.24 \\
Economic efficiency (\%) & 2.51 & 2.63 & 2.81 & 2.71 & 2.88 & 3.05 \\
\hline
\end{tabular}

Calculation based on the following price in Egyptian pound (L.E.) per ton at 2014, total mixed ration $($ TMR $)($ control $)=1700$ L.E/ton, TMR containing untreated guar korma meal $=1565$ L.E/ton, TMR containing guar korma meal treated with heat $=1580$ L.E/ton, TMR containing guar korma meal treated with soaking $=1580$ L.E/ton, TMR containing guar korma meal treated with ethanol=1580 L.E/ton, TMR containing guar korma meal treated with lactic acid bacteria $=1560$ L.E/ton. The price of one $\mathrm{kg}$ of live body weight was 33 L.E.

Price of daily gain (L.E)

Economic efficiency $(\%)=$

Average daily feed cost (L.E)

\section{Blood biochemical and serum constituents:}

The results of blood serum constituents in Barki lambs fed the experimental TMR's are presented in Table (10). Except for cholesterol, total protein, albumin, globulin and their ratio the other serum metabolites were not significantly $(\mathrm{P}>0.05)$ influenced by the dietary treatments. Lower $(\mathrm{P}<0.05)$ value of cholesterol was obtained with TMRU may be due to the high saponins concentration. Saponins have the effect of lowering serum cholesterol levels in sheep (Cerci et al., 2011). Saponins form insoluble complexes with cholesterol in the digestive system. Therefore, they inhibit the intestinal absorption of endogenous and exogenous cholesterol and the raising of the bile acid and neutral sterols by fecal defecation (Lima et al., 2012; Singh et al., 2012 and Elseed et al., 2013). The obtained serum total protein 


\section{Shwerab et al.}

values for the treated guar meal containing rations showed that the tannins level of the treated guar meal is safe and beneficial, and not detrimental, because tannins at low levels are beneficial as they impact some qualities of rumen undegradable protein, thus improving protein availability and utilization. Also, our findings were in consistent with Lohakare et al. (2006) who reported that blood glucose levels were not influenced by different dietary protein treatments in crossbred cows. Moreover, they were within the normal average as described by Gudev et al. (2005). Generally the values obtained of blood constituents in this study indicate normal physiological and healthy status of both lamb groups.

Table (10): Blood serum parameters of male lambs fed the experimental TMR's.

\begin{tabular}{lcccccccc}
\hline Item & \multicolumn{9}{c}{ Experimental TMR's } & & \\
\cline { 2 - 8 } & TMR & TMRU & TMRH & TMRS & TMRE & TMRB & SEM & Sig. \\
\hline Glucose mg/dl & 58.73 & 57.26 & 58.03 & 57.48 & 59.68 & 59.81 & 0.95 & NS \\
Total protein (TP), g/dl & $7.63^{\mathrm{a}}$ & $6.57^{\mathrm{b}}$ & $7.15^{\mathrm{ab}}$ & $7.11^{\mathrm{ab}}$ & $7.68^{\mathrm{a}}$ & $7.74^{\mathrm{a}}$ & 0.12 & $*$ \\
Albumin(A), g/dl & $4.08^{\mathrm{ab}}$ & $3.38^{\mathrm{c}}$ & $3.81^{\mathrm{b}}$ & $3.76^{\mathrm{b}}$ & $4.17^{\mathrm{a}}$ & $4.22^{\mathrm{a}}$ & 0.08 & $*$ \\
Globulin(G), g/dl & $3.55^{\mathrm{a}}$ & $3.19^{\mathrm{b}}$ & $3.34^{\mathrm{ab}}$ & $3.35^{\mathrm{ab}}$ & $3.51^{\mathrm{a}}$ & $3.52^{\mathrm{a}}$ & 0.04 & $*$ \\
A / G ratio & $1.149^{\mathrm{bc}}$ & $1.059^{\mathrm{d}}$ & $1.140^{\mathrm{c}}$ & $1.122^{\mathrm{c}}$ & $1.188^{\mathrm{ab}}$ & $1.198^{\mathrm{a}}$ & 0.01 & $*$ \\
Urea, mg/dl & 28.91 & 27.03 & 27.64 & 27.41 & 28.04 & 28.23 & 0.42 & $\mathrm{NS}$ \\
Creatinine, mg/dl & 1.12 & 1.02 & 1.03 & 1.06 & 1.08 & 1.10 & 0.11 & $\mathrm{NS}$ \\
Cholesterol mg/dl & $105.18^{\mathrm{a}}$ & $78.11^{\mathrm{d}}$ & $92.42^{\mathrm{b}}$ & $85.97^{\mathrm{c}}$ & $94.13^{\mathrm{b}}$ & $93.71^{\mathrm{b}}$ & 2.04 & $*$ \\
AST, u/l & 29.88 & 30.36 & 30.04 & 30.02 & 29.96 & 29.83 & 0.43 & $\mathrm{NS}$ \\
ALT, u/l & 18.79 & 19.03 & 18.12 & 18.27 & 17.86 & 17.75 & 0.79 & $\mathrm{NS}$ \\
\hline
\end{tabular}

$* P<0.05$ and N.S = Not significant.

$a, b, c$ and $d$, means in the same row with different superscripts are significantly differ $(P<0.05)$.

SEM: standard error of mean; Sig.: significant.

\section{CONCLUSION}

The major problem with utilizing GKM as a feed source has been stated for its toxicity. This is attributed by to the presence of the anti-nutritive compounds. However, the methods applied in this study were proved to have positive effect on better feed intake and performance of animals. The elimination of saponins and other anti-nutritive compounds by either treatment with LAB or ethanol improved the utilization of GKM as a good protein source. However, further studies needed for long run trials in order to define the metabolic compounds could be found in the end products (meat and milk) of animals fed such GKM.

\section{REFERENCES}

Abo El-Fadel, .M.H.; A.M. Husseinand and A.H. Mohamed (2011). Incorporation Jatropha Curcas Meal on Lambs Ration and It's Effect on Lambs Performance. Journal of American Science, 7(2):129-132.

Ahmad, V.U.; S. Perveen and S. Bano (1990). Saponins from the leaves of Guaiacum officinale. Phytochemistry 29: 3287-3290.

Ahmed, M. B.; R. A. Hamed; M.E. Ali; A. B. Hassan and E. E. Babiker (2006). Proximate Composition, Antinutritional Factors and Protein Fractions of Guar Gum Seeds as Influenced by Processing Treatments. Paki. J.Nutr., 5 (5): 481-484.

Al-Rabbat, M.F.; R.L. Baldwin and W.C. Weir (1971). In vitro nitrogen-treacer technique for some kinetic measures of rumen ammonia. J. Dairy Sci., 54: 150.

A.O.A.C. (1995). Official Method of Analysis (15 ${ }^{\text {th }}$ Ed.) Association of Official Analytical Chemists. Washington, Virginia Il, U.S.A.

APEDA (2011). Agri Exchange Ready Reckoner Series Commodity: GUARGUM, http://agriexchange. apeda. gov.in. Accessed on January 18, 2013. 
Avato, P.; R. Bucci; A. Tava; C. Vitali; A. Rosato; Z. Bialy and M. Jurzysta (2006). Antimicrobial activity of saponins from Medicago spp.: Structure-activity relationship. Phytother Res., 20:454-457.

Bargo, F.; D.H. Reate; F.J. Santini and L.D. Muller (2001). Ruminal digestion by dairy cows grazing winter oats pasture supplemented wit different levels and sources of protein. J. Dairy Sci., 84: 2260 2272.

Basso, F.C.; A.T. Adesogan; E.C. Lara; C.H. Rabelo; T.T. Berchielli; I.A. Teixeira; G.R. Siqueira and R. A. Reis (2014). Fermentation, microbial protein yield, and growth performance of lambs effects of feeding corn silage inoculated with microbial additives on the ruminal J. Anim.Sci.:5640-5650.

Berthelot, M. (1959). Estimation of serum urea .Report Chem. Applique 1: 248.

Borhami, B.E.A.; K. El-Shazly; A.R. Abou-Akkada; M.A., Naga; A.M. Nour and M.A. Abaza (1979). Nitrogen $(15 \mathrm{~N})$ utilization and microbial protein synthesis in the rumen of urea fed cattle. J. Anim. Sci. 49: 1306.

Borhami, B.E.A.; W.G. Fahmy and K. El-Shazly (1992). Rumen environment microbial protein synthesis and nitrogen balance in sheep. In: A Proceeding of "Manipulation of rumen micro-organisms". Inter. Conf. Egypt from 20-23 Sept. 1992.

Bruggeman, L. and D. Giesecke (1976). The effect of urea on the rumen microbiology and metabolism. In urea and protein supplement. M.B.Briggs Ed Pergamon Press, pp. 125.

Carrol, E.J. and R.E. Hungate (1954). The magnitude of microbial fermentation in the bovine rumen. Appl. Microbiol., 2: 205.

Cerci, I.H.; M. Ciftci; M. Bahsi and U. Kihnc (2011). Cholesterol and fatty acid composition of lambs serum and offal as affected by alfalfa and concentrate. Veterinarski arhiv, 81 (5): 575-584.

Difco, M. (1984). Dehydrated Culture Media Reagents for Microbiology, 10th edition, Difco Laboratories Incorporated Detroit, Michigan, USA. Pp. 689.

Doumas, B.; W. Walson and H. Blgga (1971). Albumin standards and measurement of serum with bromocresol green. Clin.Chem. Acta, 31: 87.

Duncan, D.B. (1955). Multiple ranges and multiple F- test. Biometric, 11: 1-42.

Elseed, A.; T. Danil; B. Elmanan and O. Ali (2013). Effects of fenugreek (trigonella foenum-graecum) seeds saponin on digestibility, n-retention, hematological parameters and blood metabolites in rabbits. World's Vet. J. 3(4): 65-73.

El-Shazly, K.; E.I. Ahmed; M.A. Naga and B.E.Borhami (1976). A calorimetric technique using chromium-ethylen diamins tetracetate for measuring rumen volume. J.Agric.Sci.Camb. 87: 369-373.

Faulkner, W.R. and J.W. King (1976). Fundamentals of Clinical Chemistry, $2^{\text {nd }}$ ed. (NW Tietz, Ed.), Saunders, Philadelphia, pp 994-998.

Galyean, M. (1989). Laboratory Procedure in Animal Nutrition Research. Department of Animal and Life Science, New Mexico State University,U.S.A., pp. 107-122.

Gemede, H. F. and N. Ratta (2014). Antinutritional factors in plant foods: Potential health benefits and adverse effects. Inte. . Nutr. and Food Sci., 3(4): 284-289.

Gilbery, T.C.; G.P. Lardy; S.A. Soto-Navarro; M.L. Bauer and J.S. Caton (2006). Effects of corn condensed distillers soluble supplementation on ruminal fermentation, digestion, and in situ disappearance in steers consuming low-quality hay. J. Anim. Sci. 84:1468-1480.

Gorrill, A.D.; D.M. Walker and J.D. Jones (1974). Rapeseed protein sources amino acid supplementation of diets for weanling rats. Can. J. Anim. Sci., 54: 659.

Gudev, D.; S. Popova-Ralcheva; P. Moneva; L. Kozelov and F. Iliev (2005). Effect of Yucca schidigera on some biochemical parameters in lambs. Biotech. in Anim. Husb., 21(5-6): 59-64.

Gupta, Y.P. (1987). Anti-nutritional and toxic factors in food legumes: a review. Plant Foods for Human Nutrition 37: 201-228.

Hassan, S.M.; A.A. Al Aqil1 and M. Attimarad (2013). Determination of crude saponin and total flavonoids content in guar meal. Adva. Medi. Plant Res., 1(1): 24-28. 


\section{Shwerab et al.}

Hassan, S.M.; A.U. Haq; J.A. Byrd; A.M. Berhow; A.L. Cartwright and C.A. Bailey (2010). Hemolytic and antimicrobial activities of saponin-rich extracts from guar meal. J Food Chem., 119:600-605.

Henry, R.J.; D.C. Cannon and J.W. Winkelman (1974). Clinical chemistry: Princeples and Techniques, 11th Ed., Happer and Row Publishers PP. 1629.

Hungate, R.E. (1965). Quantitative aspects of the rumen fermentation. In: Physiology of Digestion in the Ruminant, Butterworth's Inc., Washington, DC.

Hussain, M.; A.U. Rehman and M.F. Khalid (2012). Feeding value of guar meal and the application of enzymes in improving nutritive value for broilers. Worl. Poul. Sci., (68): 253-268.

Huston, J.E. and M. Shelton (1971). An evaluation of various protein concentrates for growing finishing lambs. J. Anim.Sci., 32(2): 334-338.

Jahani-Azizabadi, H.; M. D. Mesgaran; A. R. Vakili; M. Vatandoost; E. A. Ghezeljeh and M. Mojtahedi (2010). The Effect of Heat or Heat-Xylose Processing on Nitrogen Fractions and in Situ/In Vitro Ruminal and Post-Ruminal Protein Disappearance of Guar Meal. Amer. J.Anim. and Vet. Sci., 5 (4): 266-273.

Kamel, H.E.M.; J. Sekine; T. Suga and Z. Morita (1995). The effect of frozen-rethawing technique on detaching firmly associated bacteria from in situ hay residues. Can. J. Anim. Sci., 75: 481 - 483.

Kamran, M.; T.N. Pasha; A. Mahmud and Z. Ali (2002). Effect of commercial enzyme (Natugrain) supplementation on the nutritive value and inclusion rate of guar meal in broiler rations. International Journal of Poultry Science, 1(6): 167-173.

Khalil, M.M. (2001). Effect of soaking, germination, autoclaving and cooking on chemical and biological value of guar compared with faba bean. Nahrung/Food 45, No. 4, pp. 246-250.

Kumar, R. (1991). Antinutritional Factors, the Potential risks of toxicity and methods to alleviate them. Proceeding of FAO Expert Consultation held at the Malaysian Agricultural Research and Development Institute, Kuala Lumpur, Malaysia. October $14^{\text {th }}-18^{\text {th }}, 1991$.

Lee, J.T.; S.C. Appleton; A.U. Haq; C.A. Bailey and A.L. Cartwright (2004). Quantitative measurement of negligible trypsin inhibitor activity and nutrient analysis of guar meal fractions. J. Agric. Food Chem., 52: 6492 - 6495.

Liener, I.E. (2003). Phytohemagglutinins: Their nutritional significance. J. Agric. Food Chem., 22: 17.

Lila, Z. A.; N. Mohammed; S. Kanda;M. Kurihara and H. Itabashi (2005). Sarsaponin effects on ruminal fermentation and microbes, methane production, digestibility and blood metabolites in steers. AsianAust. J. Anim. Sci., 18(12): 1746-1751.

Lima F.; C. Ribeiro; D. Andrade;G. Costa; H. Pires; V. Guimaraes; M. Haraguchi and M. Fioravanti (2012). Effects of Brachiaria brizantha Hay Containing a Steroidal Saponin in Lambs. IJPPR, (2): 2026.

Lohakare, D.; J.D. Pattanaik, and S.A. Khan (2006). Effect of dietary protein levels on the performance, nutrient balances, metabolic profile and thyroid hormones of crossbred calves. Asian-Aust. J. Anim. Sci., 19: 1588-1596.

Lu, C.D.; M.J. Potchoiba; T. Sahlu and J.R. Kawas (1990). Performance of dairy goats fed soybean meal or meat and bone meal with or without urea during early lactation. J. Dairy Sci., 73: 726.

Lund, P.; M. R. Weisbjerg and T. Hvelplund (2008). Profile of digested feed amino acids from untreated and expander treated feeds estimated using in situ methods in dairy cows. Livestock Sci., 114(1): 108116.

Ma, Y.X.; H.Z. Fu; M. Li; W. Sun; B. Xu and J.R. Cui (2007). An anticancer effect of a new saponin component from Gymnocladus chinensis Baillon through inactivation of nuclear factor-kappa B. Anticancer Drugs, 18:41-46.

Mahdavi, A.M.; N.M. Torbatinejad; F. Moslemipur and R. Samiei (2010). Evaluation of guar meal replacement potential instead of some conventional meals for feedlot lambs. Proc. Aust. Soc. Anim. Prod. 28: 69-70.

Makkar, H.P. and K. Becker (1993). Behaviour of tannic acid from various commercial sources towards some chemical and protein precipitation assays. J. Sci. Food Agric., 62: 295-299. 
Makkar, H.P.S. (2000). Quantification of Tannins in Tree Foliage. A Laboratory Manual for the FAO/IAEA Coordinated .Research Project on the Use of Nuclear and Related Techniques to Develop Simple Tannin Assays for Predicting and Improving the Safety and Efficiency of Feeding Ruminants on Tanniniferous Tree Foliage.FAO/IAEA Working Document, IAEA, Vienna, Austria, p. 38.

Mathur, O.P. and C.S. Mathur (1989). Feeding of protected protein and urea supplementation for enhanced growth and feed utilization in Magra lambs. Indian J. Anim. Nutr., 6(3): 274-27.

McDonald, I. (1981). A revised model for the estimation of protein degradability in the rumen. J. Agric. Sci. Camb., 96: 251.

Mehrez, A.Z. and E.R. Ørskov (1977). A study of the artificial fibre bag technique for determining the digestibility of feeds in the rumen. J. Agri. Sci., Camb., 88: 645- 650.

Mishra, A.; S.K. Sarkar; S. Ray and S. Haldar (2013). Effects of partial replacement of soybean meal with roasted guar korma and supplementation of mannanase on performance and carcass traits of commercial broiler chickens. Veterinary World, (6): 693-697.

NRC (1994). Nutrient requirements of sheep. Academy of Sciences. National Research Council, Washington, D.C.

Nassib, A.M.; S.A. Khalil and A.H. Hussein (1991). Faba bean production and consumption in Egypt. Options Mediterraneees - Serie Seminaires, 10: 127-131.

Nidhina, N. and S.P. Muthukumar (2015). Antinutritional factors and functionality of protein-rich fractions of industrial guar meal as affected by heat processing. Food Chemistry 173: 920-926.

Nkosi, B.D.; R. Meeske; T. Langa and R.S. Thomas (2011). Effects of bacterial silage inoculants on whole-crop maize silage fermentation and silage digestibility in rams. S. Afr. J. Anim. Sci. 41:350359.

Ørskov, E.R. and I. McDonald (1979). The estimation of protein degradability in the rumen from incubation measurements weighed according to rate of passage. J. Agric. Sci. Camb., 92: 499.

Rajput, L.P.; K.N. Murthy and S. Ramamani (1987). Antinutritive effects and proximate composition of guar meals (Cyamopsis tetragonoloba). J. Food Sci., 52 (6): 1755 - 1757.

Rakshit, K.D.; J. Darukeshwara; K. Rathina Raj; K. Narasimhamurthy; P. Saibaba and S. Bhagya (2008). Toxicity studies of detoxified Jatropha meal (Jatropha curcas) in rats. Food Chem. Toxicol., 46(12): 3621-3625.

Rattanachaikunsopon P. and P. Phumkhachorn (2010). Lactic acid bacteria: their antimicrobial compounds and their uses in food production. Annals of Biological Research, 1 (4): 218-228.

Reitman, S. and S. Frankel (1957). A calorimetric method for the determination of serumglutamic oxaloacetic and glutamic pyruvic transaminases. Amer. J. Clinc. Path., 28: 56.

Salehpour, M. and K. Qazvinian (2011) . Effects of feeding different levels of guar meal on performance and blood metabolites in Holstein lactating cows. lucrări ştiinţifice - vol. 55, seria zootehnie :196-200.

Salem, S.A.Y. (2006). Nutritional evaluation of some fodder shrubs and industrial by-products as feed blocks by goats in Sini. M.Sc. Thesis, Faculty of agriculture, Cairo University, Egypt.

SAS (2000). SAS users guide: Statistics, SAS Inst., Inc., Cary N.C., USA.

Shahbazi, H. R. (2012). Dietary Inclusion of Guar Meal Supplemented by ( $\beta$-mannanase I) Evaluation Performance of Laying Hens. Global Veterinaria 9 (1): 60-66.

Shanthakumari, S.; V. Mohan and J. Britto (2008).Nutritional evaluation and elimination of toxic principles in wild yam (Dioscorea spp.). Trop. and Subtrop. Agro., (8): 319 - 225.

Sharif, M.; M. Nazar; J. Sultan; M. Bilal; M. Shahid and A. Hussain (2014). Effect of replacing cotton seed cake with guar meal on growth performance and economics in sahiwal calves. J. Anim. \& Plant Sci., 24(Suppl. 1): 28-32.

Shi, J.; S. J. Xue; Y.M.D. Li; Y. Kakuda and Y. Lan (2009).Kinetic study of saponins B stability in navy beans under different processing conditions. J.Food Engi. 93:59-65. 


\section{Shwerab et al.}

Singh, S.P.; R.K. Mehla and M. Singh (2012). Plasma hormones, metabolites, milk production, and cholesterol levels in Murrah buffaloes fed with Asparagus racemosus in transition and postpartum period. Trop. Anim. Health Prod., 44:1827-1832.

Smith, C.; W. VanMegen; L. Twaalhoven and C. Hitckcock (1980). The determination of trypsin inhibitor levels in foodstuffs. J. Sci., Food Agric., 3:341-350.

Soetan, K. and O. Oyewol (2009). The need for adequate processing to reduce the antinutritional factors in plants used as human foods and animal feeds: A review. Afri. Food Sci., 3 (9): 223-232.

Stein, E.A. (1986). Textbook of Clinical Chemistry, NW Tietz, ed. W.B. Saunders, Philadelphia, pp. 879$886,1818-1829$.

Tasneem, R. and N. Subramanian (1990). Nutritional quality of aqueus alcohol extracted Guar (Cyamopsis tetragonoloba) meals. J.Agric. food chem. 38, 1926-1929.

Thalib, A.; Y. Widiawati; H. Hamid; D. Suharman and M. Sabrani (1996). The effects of saponin from Sapindus rarak fruit on rumen microbes and performance of sheep. Jurnal Ilmu Ternak dan Veteriner., 2: 17-21.

Tran, G. (2013). Guar (Cyamopsis tetragonoloba) forage, seed and meal. Feedipedia.org. A programme by INRA, CIRAD, AFZ and FAO. http://www.feedipedia.org/node/311 last updated on August 10, 2013, 22:40.

Trinder, P. (1969). Determination of blood glucose using an oxidase-peroxidase system with a noncarcinogenic chromogen. J. Clin. Pathol., 22(2):158-61.

Turki, I.Y.; O.A. Elkadier; M. ELAmin; D. El. Zuber and A.A. Hassabo (2011). Effect of Guar Meals and Oilseed Cakes on Carcass Characteristics and Meat Quality Attributes of Beef Cattle. ACTBiotechnology Research Communications, 1(2) 66-75.

Vairtrash, L.A. and N.A. Laptera (1988). Colorimetric determination of phytate in unpurified extracts of seeds and the products of their processing. Anal Biochem., 175:227-230.

Walker, D.J. (1965). Energy metabolism and rumen microorganisms. In: Physiology of Digestion in the Ruminants. Butterowrth Inc., Washington, DC.

Warner, A.C.I. (1964). Production of volatile fatty acids in the rumen, methods of measurement. Nutr. Abst. and Rev., 34: 339.

Wina, E. (2012). Saponins: Effects on Rumen Microbial Ecosystem and Metabolism in the Rumen. Dietary Phytochemicals and Microbes: 311-350. 


\section{عمرو محمد حلمى شويرب، محد سمير محمود خليل، أمانى أمين خيال، أيمن عبد المحسن حسن و محمد حلمى ياقوت.



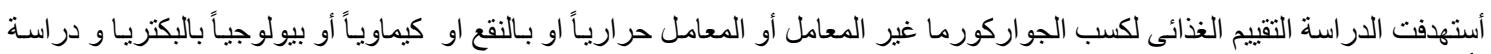



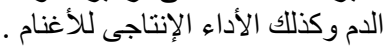

و كانت مخاليط العلائق المتكاملة المستخدمة كما يلى : لالئل 1 1. مخلوط علف متكامل (كنترول).

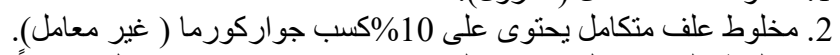

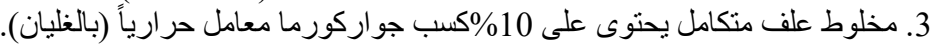

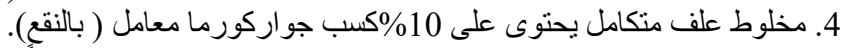

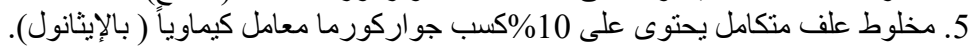

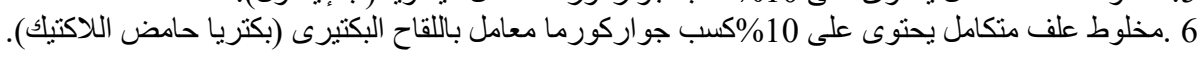



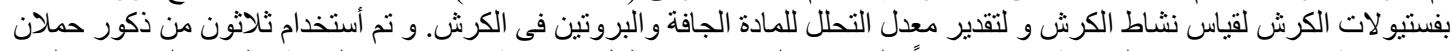

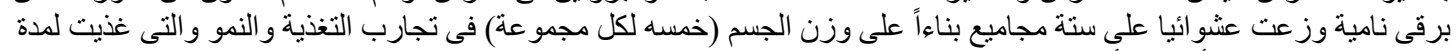



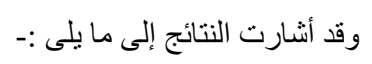

ـ ـ أدت كل المعاملات المستخدمة الى خفض تركيزات المو اد المثبطة للتخذية الى الحدود الأمنة لإستخدامها فى علائق المجترات.

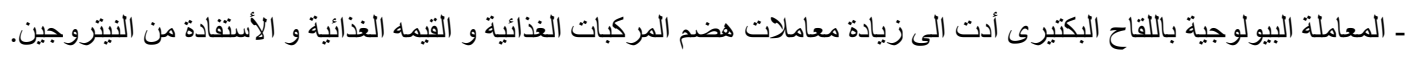



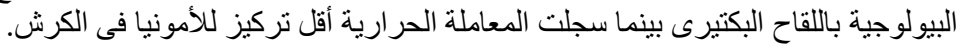

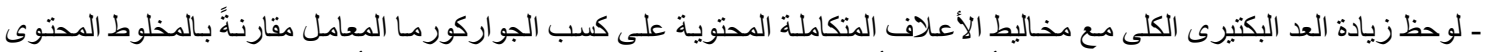

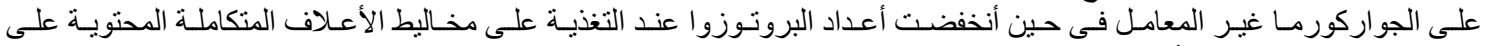





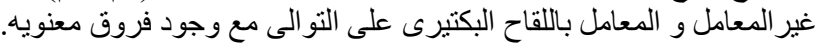

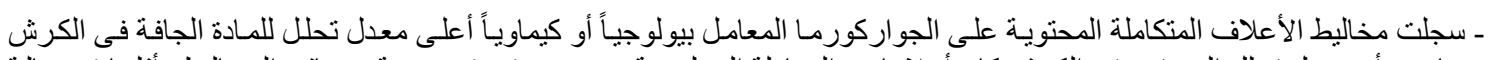

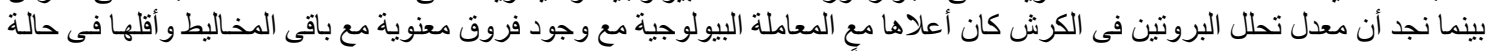



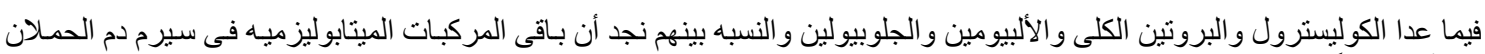
لا لا تتأثر معنوياً بإختلاف المعاملات.

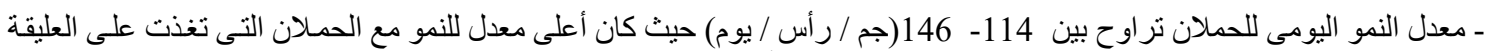

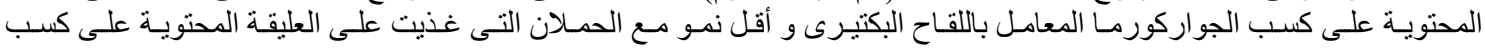
الجواركورما غير المعامل مع وجود فروق معنوية. ـ ومن الوجهه الإقتصادية أدت المعاملات البيولوجية باللقاح البكتيرى و كذلك المعائة المعاملة الكيماوية إلى خفض تكلفة العليقة مقارنة بباقى العلائق.

وبصفة عامها يمكن القول أن المعاملة باللقاح البكتيرى و كذلك المعاملة بالإيثانول تعتبر من الطرق المناسبة للتخلص من التركيزات

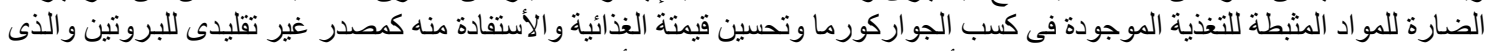

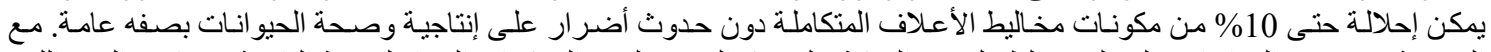

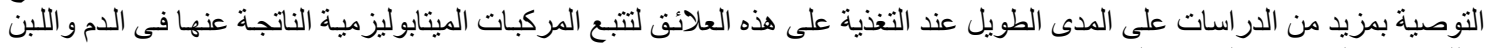

و اللحوم فى الحيو انات المغذاة عليها. 